\title{
SOIL ATTRIBUTES AND THE EFFICIENCY OF SULFENTRAZONE ON CONTROL OF PURPLE NUTSEDGE (Cyperus rotundus L.)
}

\author{
Pedro Luís da Costa Aguiar Alves ${ }^{1}$; José Marques Júnior ${ }^{2 *}$; Antonio Sergio Ferraudo ${ }^{3}$ \\ ${ }^{1}$ UNESP/FCAV - Depto. de Biologia Aplicada à Agropecuária - Rod. Prof. Paulo Donato Castellane, s/n. 14884 -900 \\ Jaboticabal, SP - Brasil. \\ ${ }^{2}$ UNESP/FCAV - Depto. Solos e Adubos. \\ ${ }^{3}$ UNESP/FCAV - Depto. de Ciências Exatas. \\ *Corresponding author <marques@fcav.unesp.br>
}

\begin{abstract}
In the soil, herbicides are submitted to absorption, leaching and degradation by physical, chemical and biological processes or absorbed by plants. All these processes are dependent on soil class and weather conditions and affect the product efficiency on weed control. The objective of this work was to investigate the influence of soil attributes on sulfentrazone efficiency for controlling purple nutsedge (Cyperus rotundus L.). Soil samples from LVAd (Typic Haplustox), LVd, LVdf and LVef (Typic Haplustox and Typic Eutrustox), NVe (Rhodic Kandiustalf), and LVd (Typic Haplustox) were collected under two crop conditions aiming to have different clay, Fe oxides, and organic matter contents. The soil samples were submitted to granulometric, chemical and mineralogical characterization. A bioassay was used to evaluate the efficacy of sulfentrazone (1.6 L c.p. ha ${ }^{-1}$ ) to control purple nutsedge on pre-emergence. The sulfentrazone behaved differently among the studied soil classes. The product efficiency decreased when the soil Fe oxide content increased, following the order: LVAd, LVd, NVe, LVef and LVdf. Clay content, ranging from 240 to $640 \mathrm{~g} \mathrm{~kg}^{-1}$, and organic matter content, ranging from 12 to $78 \mathrm{~g} \mathrm{~kg}^{-1}$, did not influence sulfentrazone efficiency.
\end{abstract}

Key words: herbicide, adsorption, Fe oxide, classes of soils

\section{ATRIBUTOS DE SOLOS E A EFICIÊNCIA DO SULFENTRAZONE NO CONTROLE DE TIRIRICA (Cyperus rotundus L.)}

RESUMO: Herbicidas aplicados ao solo são submetidos à adsorção, lixiviação e degradação por processos físicos, químicos e biológicos, além da absorção pelas plantas. Todos esses processos são afetados pela classe dos solos onde foram aplicados e das condições climáticas reinantes logo após a aplicação, que afetarão a eficiência dos produtos no controle de plantas daninhas. Investigaram-se as influências dos atributos de solos e condições de cultivo na eficiência do herbicida sulfentrazone no controle da planta daninha tiririca (Cyperus rotundus L.). O Latossolo Vermelho-Amarelo Distrófico (LVAd), o Latossolo Vermelho (LVd - Distrófico; LVdf - Distroférrico; LVef - Eutroférrico) e o Nitossolo Vermelho Eutrófico (NVe) foram coletados sob duas condições de cultivo, visando obter solos com teores diferenciados de argila, óxido de ferro e matéria orgânica. As amostras dos solos foram submetidas à caracterização granulométrica, química e mineralógica e, em seguida, utilizadas no bioensaio de avaliação da eficiência do sulfentrazone (1,6 L p.c. ha $\left.{ }^{-1}\right)$ no controle da tiririca em condições de pré-emergência. O sulfentrazone apresentou comportamento diferenciado entre as classes de solos estudados e a sua eficiência diminuiu com o aumento do teor de óxido de ferro nos solos, na seguinte ordem: LVAd, LVd, NVe, LVef e LVdf, sendo que as variações nos teores de argila $\left(240\right.$ a $\left.640 \mathrm{~g} \mathrm{~kg}^{-1}\right)$ e da matéria orgânica $\left(12\right.$ a $\left.78 \mathrm{~g} \mathrm{~kg}^{-1}\right) \mathrm{dos}$ solos não interferiram na eficiência do sulfentrazone.

Palavras-chave: herbicida, adsorção, óxidos de ferro, classes de solos

\section{INTRODUCTION}

Purple nutsedge was classified among the world's ten worst weeds, infesting the most varied crops (Holm, 1977). In Brazil, purple nutsedge is one of the worst and most frequent weeds of the sugar cane (Saccharum officinarum L.) crop, especially in the region of Ribeirão Preto (SP), where it causes a productivity reduction of up to $20 \%$ (Lorenzi, 1988; Kuva, 1999).
Sulfentrazone (N - [2,4-dichloro-5- [4(difluoromethyl)-4,5- dihydro-3 methyl -5-oxo- $1 \mathrm{H}$ 1,2,4-triazol -1- il] methanesulfonamide), from the chemical group aril triazolinones is a herbicide formulated in concentrated suspension, containing $500 \mathrm{~g}$ a.i $\mathrm{L}^{-1}$. Besides its application in industries, it is preferentially for application in pre-emergence conditions controlling several species of dicotyledonous and monocotyledonous weeds associated with the sugar cane and soybean 
(Glycine max L.) crops (Orsi Jr., 1997; Rodrigues \& Almeida, 1998).

The herbicide is commonly applied through pulverization, which may target weeds leaves and/or the soil, and may or may not be mechanically incorporated. In either case, it may be partly absorbed by colloidal particles, leached and degraded by physical, chemical and biological processes or absorbed by the plants (Velini, 1992). All those processes are dependent on the soil and climatic conditions and on the herbicide characteristics. The understanding of such processes is key to predict the behavior of this herbicide in the soil, for selection of adequate dosage, and to avoid damages to the environment and to subsequent crops. Among the soil components, the clay fraction is one of those chiefly responsible for the surface phenomenon, where the main chemical, physicalchemical and biological reactions occur in response to the behavior of the applied products (Matallo, 1999).

Besides the clay content, $\mathrm{pH}$, organic matter, total Fe content, and the crystalline degree of Fe oxides may also affect efficiency of the herbicide and also influence losses by leaching (Upchurch, 1966), contamination of underground waters (O'Connor \& Wierenga, 1973), plant-herbicide-environment interaction, as well as the persistence and decomposition of herbicide residuals in the soil (Matallo, 1999). The adsorption of organic molecules has strong dependence on the type of reactive functional groups, notably among them are the $\mathrm{Fe}$ and $\mathrm{Al}$ oxide and hydroxides in low pH conditions (Evanko \& Dzombak, 1998). In this environment, the anionic organic molecules may be exchanged with - $\mathrm{OH}$ or $-\mathrm{OH}_{2}$ groups from the $\mathrm{Fe}$ and $\mathrm{Al}$ oxide and hydroxides, in which the density of the $\mathrm{Fe}-$ or $\mathrm{Al}-$ oxygen bond charge is decreased due to its protonation. The sorption and desorption processes of herbicides may also be affected by chemical constituents of the soil in the same way as glyphosate, which competes with phosphorous for sorption specific sites. Such competition becomes important only when the phosphorous levels rates are higher than $1000 \mathrm{mg} \mathrm{dm}^{-3}$, however (Prata et al., 2003).

Regitano et al. (2000), performing studies on the behavior of imazaquin in highly weathered soils, showed that due to the $\mathrm{pH}$ range most common of agricultural tropical soils ( 5.0 to 6.5 , in which $\mathrm{pH}>\mathrm{pK}_{\mathrm{a}}$ ), and to its negative liquid balance of electric charges, the imazaquin dissociates into organic anion, showing low sorption due to repulsive electrostatic forces. Other studies are conclusive on the participation of $\mathrm{Fe}$ and $\mathrm{Al}$ oxide and hydroxides on herbicide sorption process (Ghorayshi \& Bergstrom, 1991; Pusino et al., 1997)

In laboratory experiments on sulfentrazone mobility and adsorption in soil samples, it was observed that the product concentration and the $\mathrm{pH}$ did influence the results. The adsorption generally decreases with the increase of $\mathrm{pH}$, however, the highest drop occurred above pKa (6.56) of the herbicide (Grey et al., 1997).
The objective of this work was to evaluate the efficiency of sulfentrazone on control the of purple nutsedge in soils with different $\mathrm{pH}$, clay content, Fe oxides and organic matter.

\section{MATERIAL AND METHODS}

The soil samples were collected at the northwest of the state of São Paulo, in Typic Haplustox and Rhodic Kandiustalf classes with $\mathrm{Fe}$ oxides content ranging from 40 to $330 \mathrm{~g} \mathrm{~kg}^{-1}$. Samples were taken from conventional cropping areas, neighboring to others of same soil class but with higher organic matter content, under woods, pasture and eucalyptus crop. For this study specifically, the soil samples were collected from areas that reported no history of sulfentrazone application.

The soils were identified, collected and classified: a) LVAd (Typic Haplustox), from a location in São Carlos $\left(22^{\circ} 00^{\prime} \mathrm{S}, 47^{\circ} 30^{\prime} \mathrm{W}\right)$, at the top of the highway to the city of Analândia (SP) under two crop conditions: eucalyptus and natural pasture; b) (LVdf) Typic Haplustox, from a location in Luiz Antônio $\left(21^{\circ} 17^{\prime} \mathrm{S}, 48^{\circ} 08^{\prime} \mathrm{W}\right)$ under natural pasture and sugar cane crops; c) NVe (Rhodic Kandiustalf), from a location in the city of Pradópolis ( $\left.21^{\circ} 17^{\prime} \mathrm{S}, 48^{\circ} 10^{\prime} \mathrm{W}\right)$ under woods and sugar cane crops; d) LVd (Typic Haplustox), in Jaboticabal $\left(21^{\circ} 15^{\prime} \mathrm{S}\right.$, $48^{\circ} 18^{\prime} \mathrm{W}$ ) under eucalyptus and soybean crops and (LVdf) Typic Haplustox under sugar cane and pasture. The crop conditions were chosen in order to simulate the effect of different surface organic matter content and their relationship with the herbicide. For analysis purposes, soil samples were collected at the depth of 0.0 to $0.2 \mathrm{~m}$, and in sufficient quantity to fill the ditches on the experimental area.

Particle size distribution was performed according to Day (1965). Determination of $\mathrm{Ca}^{2+}, \mathrm{Mg}^{2+}, \mathrm{K}^{+}$(SB) and $\mathrm{P}$ contents was performed according to Raij et al. (1987). The $\mathrm{pH}$ was determined from a 1:25 soil: $\mathrm{CaCl}_{2}$ $\left(0.01 \mathrm{~mol} \mathrm{~L}^{-1}\right)$ solution. The $\mathrm{Fe}$ oxide $\left(\mathrm{Fe}_{2} \mathrm{O}_{3}\right)$ was determined after digestion with $\mathrm{H}_{2} \mathrm{SO}_{4}(1: 1)$, according to the method described by Vettori (1969), and modified by EMBRAPA (1979). The free Fe oxides $\left(\mathrm{Fe}_{d}\right)$ were extracted with dithionite-citrate-sodium bicarbonate (DCB) (Mehra \& Jackson, 1960), and the poorly crystallized Fe oxides $\left(\mathrm{Fe}_{\mathrm{o}}\right)$ were extracted with ammonium oxalate (Schwertmann, 1964). Subsequently, $\mathrm{Fe}_{\mathrm{d}}$ and $\mathrm{Fe}_{\mathrm{o}}$ were determined using atomic absorption spectrophotometry.

The experiment was arranged in a randomized complete block design with ten treatments and three replicates, with a paired control for each soil class (with no herbicide application), accomplishing 60 experimental plots. Results were submitted to analysis of variance and treatment means were separated using Tukey's test $(P<0.05)$. To investigate the effect of sulfentrazone application as a function of cropping depth of purple nut- 
sedge tuber, treatments were arranged in a $3 \times 10$ factorial experiment (three planting depths and 10 soil treatment combinations) for analysis of variance.

The bioassay was conducted with no water restriction on an area infested by signalgrass (Brachiaria decumbens Stapf.) with low occurrence of purple nutsedge. Initially, glyphosate ( $\mathrm{N}$ - [phosphonomethyl] glycine) $\left(4.0 \mathrm{~L} \mathrm{c.p.} \mathrm{ha}^{-1}\right)$ was applied on the total area. One week later, 60 ditches were opened (three rows of 20 ditches $1 \mathrm{~m}$ apart) using a power shovel. Then the ditches were manually shaped into dimensions of $0.5 \times 0.5 \times 0.5$ $\mathrm{m}$. After preparation, the experimental area was kept free of weeds through manual hoeing and/or through periodic glyphosate applications. Soil samples were sifted with a 5 -mm sieve and placed in ditches of respective treatments $\left(0.125 \mathrm{~m}^{3} / \mathrm{ditch}\right)$ and dampened with water afterwards. Periodic dampening of the soils continued for 15 days after preparation of the experimental area in order to allow better reorganization. After the dampening period, twelve purple nutsedge tubers were planted in each experimental unit (four tubers each at 5,10 and $15 \mathrm{~cm}$ of depth) resulting on a final density similar to densities found in previous surveys ( 48 tubers $\mathrm{m}^{-2}$ ). The tubers were previously selected based on vigor (hardness to touch and visual appearance) and size ( $2.0 \mathrm{~cm}$ average) per ditch. Immediately after planting of the tubers, performed in October, and until the end of the experimental period, which was in November, the plots were kept wet through irrigation with 10 $\mathrm{mm}$ of water every two days.

Twenty-four hours after planting, at the purple nutsedge pre-emergence stage, sulfentrazone was applied at equivalent rate of $1.6 \mathrm{~L} \mathrm{c.p.} \mathrm{ha}^{-1}$ on plots corresponding to treatments, except for the control. The sulfentrazone application was performed with costal pulverizing at constant pressure of $23 \mathrm{kgf} \mathrm{m}^{-2}$ (compressed air), equipped with a bar with two nozzles XR 11002 and regulated for a consumption of $200 \mathrm{~L} \mathrm{ha}^{-1}$. At the time of application (5:00 p.m.), air and soil $(0.05 \mathrm{~m})$ temperature was $26^{\circ} \mathrm{C}$ and the air relative humidity $61 \%$, with light windblast and the sky was clear.

Controlled visual evaluations were performed on the purple nutsedge plants according to ALAM (1974) ranking scale. Those evaluations were performed at days 15 and 35 after herbicide application. At the end of the experimental period (50 days after the application), the plots were dismounted and plants and purple nutsedge tubers were removed according to the original planting depth. The plants were afterwards separated into aerial and tuber parts and the tubers were separated into apparently dead or alive. Based on the total number of tubers counted at the end of the study, the multiplication rate (final number of tubers/number of cropped tubers) was calculated. The apparently alive tubers were submitted to the tetrazolium $(2,3,5$ triphenyltetrazolium chloride) topographic test $(1 \% \mathrm{v} / \mathrm{v})$ to determine their viability. The different parts of the plant were dried in a forced-air oven at $70^{\circ} \mathrm{C}$ for $96 \mathrm{~h}$ to determine the dry mass.

All results from the sulfentrazone application effect on the analyzed characteristics of purple nutsedge plant for each soil class were standardized into reduction percentage relative to the corresponding untreated control. Those values were afterwards correlated to the following analyzed soil attributes: organic matter, $\mathrm{pH}$, bases saturation (V\%), $\mathrm{Fe}$ oxides $\left(\mathrm{Fe}_{2} \mathrm{O}_{3}\right.$ and $\left.\mathrm{Fe}_{\mathrm{d}}\right)$ and clay content, and submitted to Cluster analysis in order to compare the degree of similarity between the groups formed (STATISTICA for Windows, 1995). The strategy used for groupings was the "linkage average", in order to distinguish groups with homogeneous characteristics, using the Euclidian distance as similarity coefficient between the taxonomical units (OTU's).

\section{RESULTS AND DISCUSSION}

There was no effect of sulfentrazone application on planting depth of tubers. Thus, planting depth data were combined and herbicide effect on purple nutsedge plants were analyzed as a function of the soil and its respective vegetation.

Although twelve purple nutsedge tubers per ditch were cropped, the number of aerial parts was 4.9 per plot, on average (Table 2), showing that less than half of the tubers emerged during the 50 days after cropping, regardless soil class and the application or not of sulfentrazone. This result, and also the lack of depth effect, is probably due to the low rainfall precipitation during the experimental period, inducing part of the tubers to quiescence state. The sulfentrazone application reduced the number of aerial parts of purple nutsedge in LVd and in LVAd. In the other soils, regardless the vegetation, the sulfentrazone application did not reduce the number of aerial arts.

With regard to the dry matter of aerial parts on the control, the LVef and LVdf soils provided the higher mass followed by the NV (woods) soil, regardless the vegetation (Table 2). The sulfentrazone application reduced the dry mass of aerial parts in all soils, except for the LV (soybean), LVef (pasture) and NVe (sugar cane) soils. Similar results were obtained with dry matter of aerial parts per plant. The sulfentrazone application reduced the dry mass of plants in soils LVdf, LVAd (eucalyptus), LVef (sugar cane) and NVe (woods).

Soils that showed visually more vigorous plants, in other words, the LVef, LVdf and NVe soils, also had the highest number of living tubers per plot (Table 2). Sulfentrazone application reduced the number of living tubers in LV (ef and df), LVAd (eucalyptus), LVd (soybean) and NVe (woods) soils, regardless the vegetation, and increased the number of dead tubers in LVAd (eucalyptus), LVdf (woods) and NVe soils. Those results are partly due to the multiplication rate (tuber production in 
sulfentrazone treated soil vs. untreated) of the cropped tubers (Table 3).

Dry mass of living tubers found in the control plots on Day 50 after cropping was higher in LVef, LVdf, NV (woods) and LVd (soybean) soils, a consequence of higher density of tubers in these soils. Sulfentrazone application reduced the dry mass of tubers found in the LVef, LVdf, LVAd (eucalyptus), LVd (soybean) and NVe (woods) soils. The LVAd, LVef and NVe soils produced tubers with higher mass. Sulfentrazone application reduced the mass of tubers only in the LVAd (regardless the vegetation), in LVd (soybean) and in NVe (woods) soils (Table 3).

LVAd and LVd (regardless the vegetation) provided the highest number of emergences per tuber; in other words, the soils had the lowest quantity of dormant tubers (Table 2). The LVef and LVdf soils, followed by $\mathrm{NVe}$, were the soils presenting the highest quantity of dormant tubers and, except for the NVe (sugar cane) soil, application of sulfentrazone reduced the number of emergences per tuber. Only in the LVAd (pasture) and LVd (eucalyptus) soils, application of herbicide induced increase in tubers emergence.

At Day 15 after the application (DAA), no acceptable purple nutsedge control by sulfentrazone was obtained in any of the treated soils, although in LVd, regardless the vegetation, a higher level of control was obtained, when compared to the other soils. At Day 35 after the application (DAA), the herbicide provided outstanding and very good control of purple nutsedge in LVd and LVAd (eucalyptus) soils, respectively (outstanding = above $91 \%$ control, very good $=$ from 81 to $90 \%$, according to ALAM scale, 1974). In LVAd (pasture) and LVef (sugar cane) soils, the control was very good, however, in the other soil classes, the control was unacceptable, especially in LVef (pasture) and NVe soils.

Pusino et al. (1997) studied the adsorption/desorption phenomenon of the imazapyr ionizable herbicide molecule by clay minerals on six Italian soils, and obtained a high correlation $(\mathrm{r}=0.98)$ of the Freundlich sorption constant $\left(\mathrm{K}_{\mathrm{f}}\right)$ with $\mathrm{pH}$ and $\mathrm{CTC}$, showing that the adsorption process is controlled by the $\mathrm{pH}$ and by the charge of components adsorbed into the soils. The organic matter adsorption was more effective at $\mathrm{pH}<5.0$. The authors also observed a higher adsorption in shapeless $\mathrm{Fe}$ oxides, especially through the non-specific bonds process.

Sulfentrazone behavior in soil, under laboratory conditions, may be affected by the type of soil and $\mathrm{pH}$, but $\mathrm{pH}$ is probably the most important factor (Grey et al., 1997). Sulfentrazone is the only one among all herbicides applied to soils in which the pKa of 6.56 is found within the range of $\mathrm{pH}$ values typical in soybean cropping areas (from 6 to 7.5). Sulfentrazone adsorption will decrease and its susceptibility to leaching will increase for $\mathrm{pH}$ values above pKa.
Clay content did not contribute significantly to the adsorption process of acid herbicides by soils (Green, 1974); however, the contribution of $\mathrm{Fe}$ and $\mathrm{Al}$ oxides and hydroxides was quite important, because the charge surface depends on the $\mathrm{pH}$ and the adsorption is an outcome of the ionic bond between minerals and the acid grouping of the molecule at low $\mathrm{pH}$ values (below the herbicide's pKa).

Loux et al. (1989) performed studies on the adsorption of the imazaquin herbicide and obtained positive correlation with the organic carbon concentration and negative correlation with the soil $\mathrm{pH}$, formulating an adsorption model with the following independent variables: $\mathrm{pH}$, organic carbon and clay percentage, with coefficient $\mathrm{R}^{2}$ of $0.909^{* *}$. The use of the regression model proposed showed good prediction of relative availability of imazaquin in soils in controlled conditions (laboratory). However, the soil-water system conditions in field are quite different. The degradation difficulties of the herbicide in the soil and the reduction of the herbicide's availability are attributed to differences between bond forces of molecules with the clay fraction colloids, thus causing short-period limitations to data extrapolations of adsorption isothermals in laboratory, for the several situations in field. Regitano et al. (2001) also verified that organic carbon and the solution $\mathrm{pH}$ were the first attributes of soil correlated to the imazaquin sorption, and the inclusion of the clay content in the regression analysis increased the model's accuracy up to $20 \%$.

Results of the Cluster analysis, however, showed that the variables (characteristics) of purple nutsedge plant that best showed the herbicide effect were: the tubers mortality rate $($ MORT $=$ NTV-NTM), the number of tubers (NT), the number of aerial parts (NPA) and dry mass per tuber (MSTP), in this order (Figure 1). When the first three characteristics were compared to the Fe oxide content in soils, the formation of three soil groups was verified: the first group, formed by LVdf soils, the second, by NVe and LVef soils and the third, by LVd and LVAd soils (Figure 2).

When soils received no sulfentrazone treatment, the purple nutsedge growing characteristics allowed for classification by three groups of soils, whereas the best growing rate occurred at the first group (LVdf), intermediate growing rate was observed at the second group (LVef-sugar cane, LVd-soybean, NVe-woods and LVAdeucalyptus), and the worst growing rate observed at the third group (LVd-eucalyptus, LVef-pasture, NVe-sugar cane and LVAd-pasture), as shown by Figure 3.

When soils received sulfentrazone treatment, the purple nutsedge growing characteristics could be grouped in three categories (Figure 4). The first group, which showed the best growing rate, or the worst control provided by the herbicide, corresponded to the group of LVdf and LVef (pasture) soils, which had higher contents of Fe 


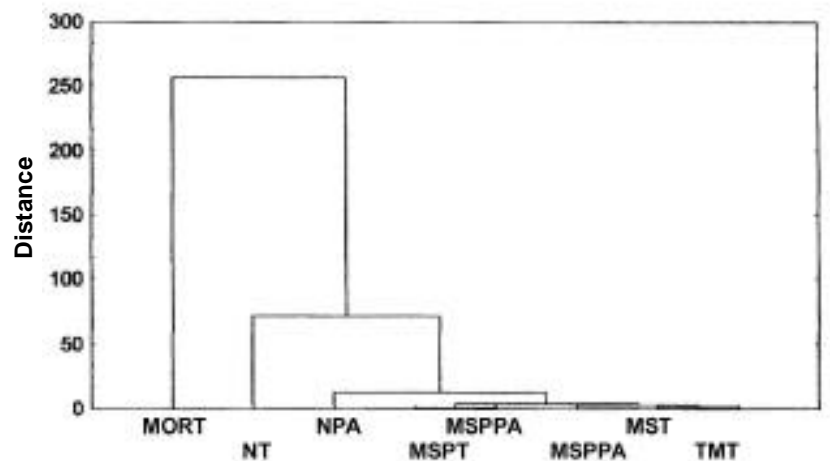

Figure 1 - Results of the groups derived from analysis for the measurable variables response to the effects of sulfentrazone applied on different soil classes. (MORT = tubers mortality rate; $\mathrm{NT}=$ number of tubers; NPA $=$ number of aerial parts; MSPT $=$ dry matter per tuber; MSPPA = dry matter per aerial part; MSPA = aerial part dry matter; MST = tubers dry matter; $\mathrm{TMT}=$ tubers multiplication rate).

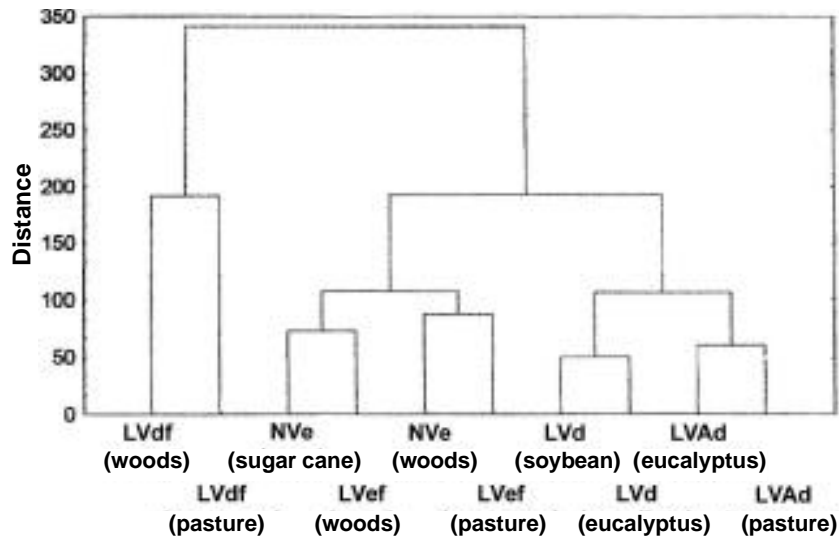

Figure 2 - Results of the groups derived from analysis for the three main variables response to $\mathrm{Fe}$ oxide content in the different soil classes LVAd (Typic Haplustox), LVd, LVdf and LVef (Typic Haplustox and Typic Eutrustox), NVe (Rhodic Kandiustalf), and LVd (Typic Haplustox).

oxides (Table 1). The second group, which showed intermediate sulfentrazone controlling, corresponded to the group of NVe and LVef (sugar cane) soils, which had intermediate contents of $\mathrm{Fe}$ oxides (Table 1). The third group, where the best purple nutsedge control by sulfentrazone was obtained, corresponded to the group of LVd and LVAd soils, which had the lowest contents of Fe oxides (Table 1).

The $\mathrm{Fe}$ oxides content strongly influenced the behavior and efficiency of the sulfentrazone herbicide on purple nutsedge control. The efficiency of such molecule decreases with the increase of those oxides content in the soil. These results are in agreement to studies by Upchurch (1966), O'Connor \& Anderson (1974) and Blanco (1979), verifying that the Fe total content and the Fe oxides crystalinity may reduce the efficiency of herbicides. This may be due to the presence of positive

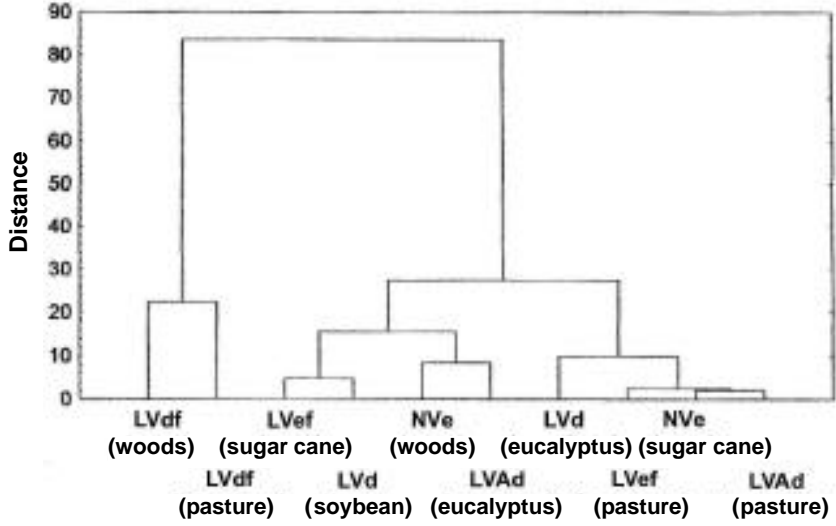

Figure 3 - Results of the groups derived from analysis for the purple nutsedge plant behavior in function of soil class and crop with no sulfentrazone application. LVAd (Typic Haplustox), LVd, LVdf and LVef (Typic Haplustox and Typic Eutrustox), NVe (Rhodic Kandiustalf), and LVd (Typic Haplustox).

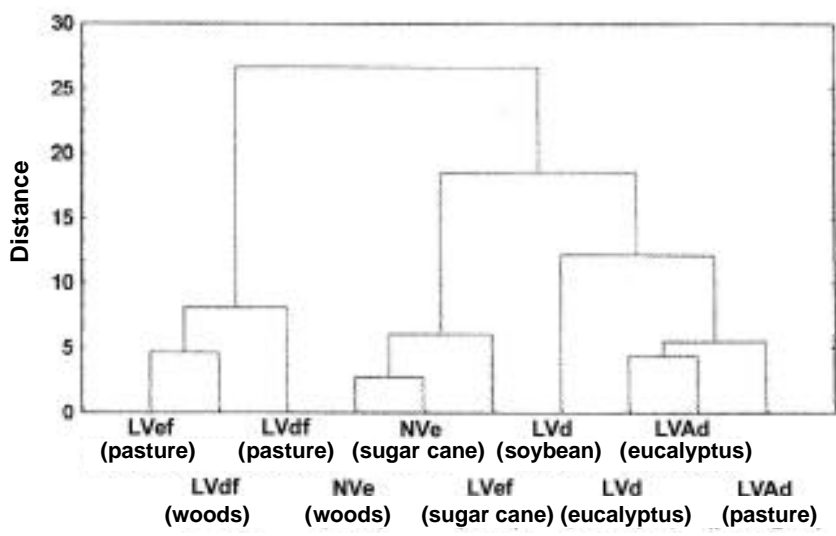

Figure 4 - Results of the groups derived from analysis for the purple nutsedge plant behavior in function of soil class and crop with sulfentrazone application. LVAd (Typic Haplustox), LVd, LVdf and LVef (Typic Haplustox and Typic Eutrustox), NVe (Rhodic Kandiustalf), and LVd (Typic Haplustox).

charges conditioning the specific or the non-specific adsorption, when performed by coulombic forces on the external part of the diffuse double layer, depending on the ionic charges from the soil solution.

Research performed on other herbicide molecules with ionic charges, such as picloram (4-amino-3,5,6trichloro-2-pyridinecarboxylic acid) (Hammaker et al., 1966), herbicides from the chemical group organic-arsenical (Dickens \& Hiltbold, 1967) and 2,4,5-T (O'Connor $\&$ Anderson, 1974), also showed results similar to results to this work, attributing the presence of $\mathrm{Fe}$ and $\mathrm{Al} \mathrm{ox}$ ide-hydroxides in soils as the cause of the differential efficiency of the studied herbicides on different types of soils. Sources of positive charges originated from the edges of clay mineral plates, or of charges associated to $\mathrm{Fe}$ and $\mathrm{Al}$ oxide-hydroxides, contribute to the herbicides adsorption process (Bailey \& White, 1970). 
Table 1 - Granulometric, chemical and Fe oxides analysis of layers from $0.0-0.2 \mathrm{~m}$ from the soils ${ }^{(1)}$.

\begin{tabular}{|c|c|c|c|c|c|c|c|c|c|c|c|c|c|}
\hline \multirow[b]{2}{*}{ Soil } & \multicolumn{3}{|c|}{ Granulometry } & \multicolumn{6}{|c|}{ Chemistry } & \multicolumn{4}{|c|}{ Fe Oxide } \\
\hline & Total Sand & Silt & Clay & $\begin{array}{c}\mathrm{PH} \\
\mathrm{CaCl}_{2}\end{array}$ & $\mathrm{MO}^{1}$ & $\mathrm{SB}^{2}$ & $\mathrm{~T}^{3}$ & $\mathrm{~V}^{4}$ & $? \mathrm{pH}^{5}$ & $\mathrm{Fe}_{2} \mathrm{O}_{3 \mathrm{t}}{ }^{6}$ & $\mathrm{Fe}_{\mathrm{d}}{ }^{7}$ & $\mathrm{Fe}_{\mathrm{o}}^{8}$ & $\mathrm{Fe}_{\mathrm{o}} / \mathrm{Fe}_{\mathrm{d}}$ \\
\hline & \multicolumn{3}{|c|}{ - $\mathrm{g} \mathrm{kg}^{-1}-\cdots$} & & $\mathrm{g} \mathrm{dm}^{-3}$ & \multicolumn{2}{|c|}{$\mathrm{mmol}_{\mathrm{c}} \mathrm{dm}^{-3}$} & $\%$ & & \multicolumn{4}{|c|}{----- g kg $^{-1}$----- } \\
\hline LVd (eucalyptus) & 720 & 30 & 250 & 4.1 & 16 & 8.5 & 50.5 & 17 & -0.8 & 65 & 48 & 6.8 & 0.14 \\
\hline LVd (soy) & 724 & 36 & 240 & 5.3 & 12 & 38.7 & 66.7 & 58 & -0.7 & 65 & 48 & 6.8 & 0.14 \\
\hline LVAd (eucalyptus) & 270 & 150 & 580 & 4.0 & 78 & 4.8 & 84.8 & 6 & -1.0 & 75 & 52 & 10 & 0.19 \\
\hline LVAd (pasture) & 420 & 70 & 510 & 4.2 & 41 & 12.5 & 110.5 & 11 & -1.0 & 74 & 37 & 9 & 0.24 \\
\hline NVe (woods) & 220 & 350 & 430 & 5.8 & 25 & 101.7 & 129.7 & 78 & -1.0 & 190 & 71 & 10 & 0.14 \\
\hline NVe (sugar cane) & 620 & 40 & 340 & 5.7 & 23 & 85.6 & 110.6 & 77 & -0.9 & 170 & 57 & 12 & 0.21 \\
\hline LVef (pasture) & 320 & 200 & 480 & 5.7 & 37 & 65.9 & 93.9 & 70 & -0.6 & 216 & 80 & 11 & 0.14 \\
\hline LVef (sugar cane) & 260 & 190 & 550 & 5.9 & 21 & 40.2 & 53.2 & 76 & -0.9 & 230 & 95 & 11 & 0.12 \\
\hline LVdf (woods) & 150 & 210 & 640 & 4.5 & 44 & 22.2 & 86.2 & 26 & -1.1 & 337 & 144 & 6.2 & 0.04 \\
\hline LVdf (pasture) & 130 & 370 & 500 & 4.5 & 36 & 13.9 & 78 & 18 & -0.9 & 337 & 144 & 6.2 & 0.04 \\
\hline
\end{tabular}

${ }^{(1)}$ LVAd (Typic Haplustox), LVd, LVdf and LVef (Typic Haplustox and Typic Eutrustox), NVe (Rhodic Kandiustalf), and LVd (Typic Haplustox). $\mathrm{MO}^{1}=$ organic matter; $\mathrm{SB}^{2}=\mathrm{Ca}+\mathrm{Mg}+\mathrm{K} ; \mathrm{T}^{3}=\mathrm{SB}+(\mathrm{H}+\mathrm{Al}) ; \mathrm{V}^{4}=100 \mathrm{SB} / \mathrm{T} ; \Delta \mathrm{pH}^{5}=\mathrm{pH}(\mathrm{KCl})-\mathrm{pH}\left(\mathrm{H}_{2} \mathrm{O}\right) ; \mathrm{Fe}_{2} \mathrm{O}_{3}(\mathrm{t})^{6}=\mathrm{Fe}$ extracted by sulfuric acid; $\mathrm{Fe}_{\mathrm{d}}{ }^{7}=\mathrm{Fe}$ extracted by dithionite-citrate-bicarbonate $(\mathrm{DBC}) ; \mathrm{Fe}_{\mathrm{o}}^{8}=\mathrm{Fe}$ extracted by ammonium oxalate.

Table 2 - Effect of sulfentrazone on the number of aerial parts (NPA), the aerial part dry matter (MSPA), the dry matter per aerial part (MSPPA), the number of dead and alive tubers (NTVM) and the number of dead tubers (NTM) of purple nutsedge on soil classes.

\begin{tabular}{lcccccccccc}
\hline \multirow{2}{*}{ Soil } & \multicolumn{2}{c}{ NPA $\left(0.25 \mathrm{~m}^{2}\right)$} & \multicolumn{2}{c}{ MSPA $\left(0.25 \mathrm{~m}^{2}\right)$} & \multicolumn{2}{c}{ MSPPA } & \multicolumn{2}{c}{ NTVM $\left(0.125 \mathrm{~m}^{3}\right)$} & \multicolumn{2}{c}{ NTM } \\
& \multicolumn{2}{c}{ ( per plant $)$} & \multicolumn{2}{c}{ NT25 $\left.\mathrm{m}^{3}\right)$} \\
\cline { 2 - 12 } & Sulf. & Test & Sulf & Test & Sulf & Test & Sulf & Test & Sulf & Test \\
\hline LVd (eucalyptus) & $3.3 \mathrm{~B}^{(2)}$ & $5.0 \mathrm{~A}$ & $0.635 \mathrm{~B}$ & $1.404 \mathrm{~A}$ & $0.200 \mathrm{~A}$ & $0.281 \mathrm{~A}$ & $10.7 \mathrm{~A}$ & $12.0 \mathrm{~A}$ & $3.3 \mathrm{~A}$ & $3.0 \mathrm{~A}$ \\
LVd (soybean) & $4.0 \mathrm{~B}$ & $7.0 \mathrm{~A}$ & $2.226 \mathrm{~B}$ & $1.344 \mathrm{~B}$ & $0.584 \mathrm{~A}$ & $0.192 \mathrm{~B}$ & $14.0 \mathrm{~B}$ & $29.0 \mathrm{~A}$ & $2.0 \mathrm{~B}$ & $5.0 \mathrm{~A}$ \\
LVAd (eucalyptus) & $3.7 \mathrm{~B}$ & $6.0 \mathrm{~A}$ & $0.765 \mathrm{~B}$ & $2.854 \mathrm{~A}$ & $0.194 \mathrm{~B}$ & $0.476 \mathrm{~A}$ & $11.0 \mathrm{~B}$ & $17.0 \mathrm{~A}$ & $2.7 \mathrm{~A}$ & $1.0 \mathrm{~B}$ \\
LVAd (pasture) & $2.7 \mathrm{~B}$ & $6.0 \mathrm{~A}$ & $0.700 \mathrm{~B}$ & $1.501 \mathrm{~A}$ & $0.191 \mathrm{~A}$ & $0.250 \mathrm{~A}$ & $15.0 \mathrm{~A}$ & $19.0 \mathrm{~A}$ & $3.3 \mathrm{~A}$ & $2.0 \mathrm{~A}$ \\
NVe (woods) & $5.0 \mathrm{~A}$ & $4.0 \mathrm{~A}$ & $1.521 \mathrm{~B}$ & $4.972 \mathrm{~A}$ & $0.233 \mathrm{~B}$ & $1.243 \mathrm{~A}$ & $16.0 \mathrm{~B}$ & $30.0 \mathrm{~A}$ & $5.3 \mathrm{~A}$ & $0.0 \mathrm{~B}$ \\
NVe (sugar cane) & $4.0 \mathrm{~A}$ & $4.0 \mathrm{~A}$ & $2.040 \mathrm{~A}$ & $1.920 \mathrm{~A}$ & $0.598 \mathrm{~A}$ & $0.480 \mathrm{~A}$ & $16.7 \mathrm{~A}$ & $18.0 \mathrm{~A}$ & $5.0 \mathrm{~A}$ & $3.0 \mathrm{~B}$ \\
LVef(pasture) & $5.3 \mathrm{~A}$ & $4.0 \mathrm{~A}$ & $7.048 \mathrm{~A}$ & $5.640 \mathrm{~A}$ & $1.292 \mathrm{~A}$ & $1.410 \mathrm{~A}$ & $24.7 \mathrm{~B}$ & $41.0 \mathrm{~A}$ & $3.7 \mathrm{~A}$ & $3.0 \mathrm{~A}$ \\
LVef (sugar cane) & $7.7 \mathrm{~A}$ & $5.0 \mathrm{~A}$ & $1.424 \mathrm{~B}$ & $8.023 \mathrm{~A}$ & $0.208 \mathrm{~B}$ & $1.604 \mathrm{~A}$ & $13.0 \mathrm{~B}$ & $26.0 \mathrm{~A}$ & $4.7 \mathrm{~A}$ & $4.0 \mathrm{~A}$ \\
LVdf (woods) & $3.7 \mathrm{~A}$ & $5.0 \mathrm{~A}$ & $3.554 \mathrm{~B}$ & $13.591 \mathrm{~A}$ & $0.581 \mathrm{~B}$ & $2.718 \mathrm{~A}$ & $29.0 \mathrm{~B}$ & $74.0 \mathrm{~A}$ & $3.0 \mathrm{~A}$ & $0.0 \mathrm{~B}$ \\
LVdf (pasture) & $6.3 \mathrm{~A}$ & $6.0 \mathrm{~A}$ & $4.733 \mathrm{~B}$ & $18.862 \mathrm{~A}$ & $0.591 \mathrm{~B}$ & $3.144 \mathrm{~A}$ & $32.7 \mathrm{~B}$ & $94.0 \mathrm{~A}$ & $1.3 \mathrm{~A}$ & $2.0 \mathrm{~A}$ \\
\hline
\end{tabular}

${ }^{(1)}$ LVAd (Typic Haplustox), LVd, LVdf and LVef (Typic Haplustox and Typic Eutrustox), NVe (Rhodic Kandiustalf), and LVd (Typic Haplustox). ${ }^{(2)}$ Averages followed by same letter are no different by the Tukey test at $5 \%$, for each variable and for soil class.

Table 3 - Effect of sulfentrazone on the tubers multiplication rate (TMT), the tubers dry matter mass (MST), dry matter mass per tuber (MSPT), the number of emergences per tuber (NBPT) and the purple nutsedge visual controlling $(\mathrm{CV})$ at days 15 and 35 after the sulfentrazone application on soil classes ${ }^{(1)}$.

\begin{tabular}{|c|c|c|c|c|c|c|c|c|c|c|}
\hline \multirow{2}{*}{ Soil } & \multicolumn{2}{|c|}{ TMT } & \multicolumn{2}{|c|}{$\operatorname{MST}\left(0.25 \mathrm{~m}^{2}\right)$} & \multicolumn{2}{|c|}{ MSPT (g per plant) } & \multicolumn{2}{|c|}{ NBPT } & \multicolumn{2}{|c|}{$\mathrm{CV}(\%)^{(3)}$} \\
\hline & Sulf & Test & Sulf. & Test & Sulf & Test & Sulf & Test & 15 & 35 \\
\hline LVd (eucalyptus) & $0.9 \mathrm{~A}^{(2)}$ & $0.0 \mathrm{~A}$ & $1.764 \mathrm{~A}$ & $1.519 \mathrm{~A}$ & $0.168 \mathrm{~A}$ & $0.127 \mathrm{~B}$ & $0.42 \mathrm{~A}$ & $0.27 \mathrm{~B}$ & $57 \mathrm{~A}$ & $92 \mathrm{~A}$ \\
\hline LVd (soybean) & $1.2 \mathrm{~B}$ & $2.4 \mathrm{~A}$ & $1.426 \mathrm{~B}$ & $6.589 \mathrm{~A}$ & $0.102 \mathrm{~B}$ & $0.227 \mathrm{~A}$ & $0.24 \mathrm{~A}$ & $0.29 \mathrm{~A}$ & $43 \mathrm{~B}$ & $92 \mathrm{~A}$ \\
\hline LVAd (eucalyptus) & $0.9 \mathrm{~B}$ & $1.4 \mathrm{~A}$ & $1.249 \mathrm{~B}$ & $4.257 \mathrm{~A}$ & $0.115 \mathrm{~B}$ & $0.250 \mathrm{~A}$ & $0.35 \mathrm{~A}$ & $0.36 \mathrm{~A}$ & $35 \mathrm{BC}$ & $81 \mathrm{~B}$ \\
\hline LVAd (pasture) & $1.2 \mathrm{~A}$ & $1.6 \mathrm{~A}$ & $2.251 \mathrm{~B}$ & $3.517 \mathrm{~A}$ & $0.135 \mathrm{~B}$ & $0.185 \mathrm{~A}$ & $0.31 \mathrm{~A}$ & $0.20 \mathrm{~B}$ & $28 \mathrm{CD}$ & $73 \mathrm{BC}$ \\
\hline NVe (woods) & $1.3 \mathrm{~B}$ & $2.5 \mathrm{~A}$ & $3.459 \mathrm{~B}$ & $10.201 \mathrm{~A}$ & $0.224 \mathrm{~B}$ & $0.340 \mathrm{~A}$ & $0.13 \mathrm{~B}$ & $0.31 \mathrm{~A}$ & $33 \mathrm{BC}$ & $55 \mathrm{D}$ \\
\hline NVe (sugar cane) & $1.4 \mathrm{~A}$ & $1.5 \mathrm{~A}$ & $2.799 \mathrm{~A}$ & $2.686 \mathrm{~A}$ & $0.166 \mathrm{~A}$ & $0.149 \mathrm{~B}$ & $0.22 \mathrm{~A}$ & $0.23 \mathrm{~A}$ & $38 \mathrm{BC}$ & $46 \mathrm{E}$ \\
\hline LVef(pasture) & $2.1 \mathrm{~B}$ & $3.4 \mathrm{~A}$ & $6.169 \mathrm{~B}$ & $10.268 \mathrm{~A}$ & $0.248 \mathrm{~B}$ & $0.250 \mathrm{~A}$ & $0.10 \mathrm{~B}$ & $0.20 \mathrm{~A}$ & $16 \mathrm{E}$ & $8 \mathrm{~F}$ \\
\hline LVef (sugar cane) & $1.1 \mathrm{~B}$ & $2.2 \mathrm{~A}$ & $1.801 \mathrm{~B}$ & $5.587 \mathrm{~A}$ & $0.146 \mathrm{~B}$ & $0.215 \mathrm{~A}$ & $0.19 \mathrm{~A}$ & $0.20 \mathrm{~A}$ & $38 \mathrm{BC}$ & 79 B \\
\hline LVdf (woods) & $2.4 \mathrm{~B}$ & $6.2 \mathrm{~A}$ & $5.921 \mathrm{~B}$ & $11.444 \mathrm{~A}$ & $0.185 \mathrm{~A}$ & $0.155 \mathrm{~A}$ & $0.06 \mathrm{~B}$ & $0.14 \mathrm{~A}$ & $18 \mathrm{DE}$ & $68 \mathrm{C}$ \\
\hline LVdf (pasture) & $2.7 \mathrm{~B}$ & $7.8 \mathrm{~A}$ & $4.779 \mathrm{~B}$ & $15.142 \mathrm{~A}$ & $0.166 \mathrm{~A}$ & $0.161 \mathrm{~A}$ & $0.07 \mathrm{~B}$ & $0.18 \mathrm{~A}$ & $18 \mathrm{DE}$ & $52 \mathrm{DE}$ \\
\hline
\end{tabular}


Other conclusive studies on the influence of $\mathrm{Fe}$ and $\mathrm{Al}$ oxide-hydroxides on the imazaquin sorption were performed by Goetz et al. (1986) and Regitano et al. (1997), who reported that the mechanism involved on the sorption of such herbicide on the surface positive charges of those oxide-hydroxides was due to anionic exchange mechanisms and/or bonding formation.

\section{CONCLUSION}

Sulfentrazone herbicide behaves differently when applied in pre-emergence conditions on the different soil classes studied.There is reduction on its efficiency on the purple nutsedge weed control (Cyperus rotundus) with increased Fe oxide content in soils. Variations on the clay content (from 240 to $640 \mathrm{~g} \mathrm{~kg}^{-1}$ ) and on the organic matter (from 12 to $78 \mathrm{~g} \mathrm{~kg}^{-1}$ ) of soils did not influence the efficiency of sulfentrazone on purple nutsedge weed controll.

\section{ACKNOWLEDGMENTS}

To José Francisco de Paula Neto, Agricultural Engineer, for the aid with soil collection and conducting the test.

\section{REFERENCES}

ASOCIACIÓN LATINOAMERICANA DE MALEZAS. Recomendaciones sobre unificación de los sistemas de evaluación en ensayos de control de malezas. ALAM, v.1, p.35-38, 1974.

BAILEY, G.W.; WHITE, J.L. Factors influencing the adsorption, desorption, and movement of pesticides in soil. Research Reviews, v.32, p.29-62, 1970.

BLANCO, H.G. Destino, comportamento e resíduos dos herbicidas no solo. Biológico, v.45, p.225-248, 1979.

DAY, P.R. Particle fractionation and particle size analyses. In: BLACK, C.A. (Ed.) Methods of soil analysis. Madison: ASA 1965. v.1, p.545546.

DICKENS, R.; HILTBOLD, A.E. Movement and persistence of methanearsonates in soil. Weed Science, v.15, p.299-304, 1967.

EMPRESA BRASILEIRA DE PESQUISA AGROPECUÁRIA. Serviço Nacional de Levantamento e Conservação de Solos. Manual de métodos de solo. Rio de Janeiro: EMBRAPA, SNLCS, 1979.

EVANDRO, C.R.; DZOMBAK, D.A. Influence of structural feactures on sorption of NOM-analogue organic acids to goethite. Enviromental Science and Technology, v.32, p.2846-2855, 1998.

GHORAYSHI, M.; BERGSTROM, L. Equilibrium studies of the adsorption of dichlorprop on 3 Swedish soil profiles. Swedish Journal of Agricultural Research, v.21, p.157-163, 1991.

GOETZ, A.J.; WEHTJE, G.; WALKER, R.H.; HAJEK, B. Soil solution and mobility characterization of imazaquin. Weed Science, v.34, p.788793, 1986.

GREY, T.L.; WALKER, RH; WEHTJE, G.R. Sulfentrazone adsorption and mobility as affected by soil and $\mathrm{pH}$. Department of Agronomy and Soil, Alabama. Weed Science, v.45, p.733-738, 1997.

GREEN, R.E. Pesticide-clay-water interactions. In: GUELZI, W.D. (Ed.) Pesticides in soil and water. Madinson: SSSA, 1974. p.3-37.

HAMMAKER, F.J.; GORING, C.A.I.; YOUNGSON, C.R. Sorption and leaching of 4-amino-3,5,6-trichloropicolinic acid in soil. Advanced Chemical Service, v.60, p.23-37, 1966.
HOLM, L.G. The world's worst weeds. Honolulu: University Press of Hawaii, 1977. 607p.

KUVA, M.A. Efeito de períodos de controle e de convivência das plantas daninhas na cultura da cana de açúcar (Saccharum sp.) no Estado de São Paulo. Piracicaba: USP/ESALQ, 1999. (Dissertação - Mestrado).

LORENZI, H. Plantas daninhas e seu controle na cultura da cana-de-açúcar. In: SEMINÁRIO DE TECNOLOGIA AGRONÔMICA., 4, Piracicaba, 1988. Anais. São Paulo: Coopersucar, 1988. p.281-301.

LOUX, M.M.; LIEBL, R.A.; SLIFE, F.W. Adsorption of imazaquin and imazethapyr on soils, sediments, and selected adsorbents. Weed Science, v.37, p.712-718, 1989

MATALLO, M.B. La reación suelo-herbicida: decomposion, resíduo y contaminación, manejo. In: CONGRESSO LATINOAMERICANO DE MALEZAS, 14., Cartagena, 1999. Cartagena: ALAM, 1999. p.3-8.

MEHRA, O.P.; JACKSON, M.L. From oxide removal from soils and clays by a dithionite-citrate system buffered with sodium bicarbonate. Clays and Clay Minerals, v.7, p.317-327, 1960.

O'CONNOR, G.A.; WIERENGA, P.J. The persistence of 2,4,5-T in greenhouse lysimeter studies. Soil Science Society of America Proceedings, v.37, p.398-400, 1973.

O'CONNOR, G.A.; ANDERSON, J.U. Soil factors affecting the adsorption of 2,4,5-T. Soil Science Society of America Proceedings, v.38, p.433436, 1974.

ORSI JR., F. Eficácia e seletividade do sulfentrazone no controle da tiririca na cultura da cana de açúcar. Planta Daninha, v.15, p.78-84, 1997.

PRATA, F.; CARDINALI, V.C.B.; LAVORENTI, A.; TOMISIELO, V.L.; REGITANO, J.B. Sorção e dessorção de glifosato em solos com distintos níveis de fósforo. Scientia Agricola, v.60, p.175-180, 2003.

PUSINO, A.; PETRETTO, S.; GESSA, C. Adsorption and desorption of imazapyr by soil. Journal of Agricultural and Food Chemistry, v.45, p.1012-1016, 1997.

RAIJ, B. van; QUAGGIO, J.A.; CANTARELLA, J.; FERREIRA, M.E.; LOPES, A.S.; BATAGLIA, O.A. Análise química do solo para fins de fertilidade. Campinas: Fundação Cargill, 1987. 170p.

REGITANO, J.B.; ALLEONI, L.R.F.; TORNISIELO, V. L. Atributos de solos tropicais e a sorção de imazaquin. Scientia Agricola, v.58, p.801807, 2001

REGITANO, J.B.; ALLEONI, L.R.F.; VITAL-TORRADO, P.; CASAGRANDE, J.C.; TORNISIELO, V.L. Imazaquin sorption in highly weathered tropical soil. Journal of Environmental Quality, v.29, p.894900, 2000.

REGITANO, J.B.; BISCHOFF, M.; LEE, L.S.; REICHERT, J.M.; TURCO, R.F. Retention of imazaquin in soil. Environmental Toxicology and Chemistry, v.16, p.397-404, 1997.

RODRIGUES, B.N.; ALMEIDA, F.S. Guia de herbicidas. 4.ed. Londrina: Edição dos Autores, 1998. 648p.

SCHWERTMANN, U. Differenzierung der eisenoxide des rodens durch extraktion mit ammoniumoxalat-lösung. Pflanzenernährung Bodenkunde, v.105, p.195-202, 1964.

STATISTICA FOR WINDOWS. Realease 5.1. General conventions. Tulsa: Statsoft, 1995.

VELINI, E.D. Comportamento de herbicidas no solo. In: SIMPÓSIO NACIONAL SOBRE MANEJO INTEGRADO DE PLANTAS PANINHAS EM HORTALIÇAS, Botucatu; 1992. Botucatu: UNESP, FCA, 1992. p.44-64.

VETTORI, L. Métodos de análise de solo. Rio de Janeiro: EMBRAPA SNLCS, 1969. 34p. (Boletim Técnico, 7).

UPCHURCH, R.P. Behavior of herbicides in soil. Research Reviews, v.16, p.45-85, 1966

$\overline{\text { Received July 31, }} 2003$

Accepted March 11, 2004 